\title{
Data on Polychlorinated Biphenyls, Dieldrin, Lead, and Cadmium in Wisconsin and Upper Michigan Tributaries to Green Bay, July 1987 through April 1988
}

By

Leo B. House

Open-File Report 89-52

Prepared by

United States Department of the Interior

Geological Survey

In cooperation with the

U.S. Environmental Protection Agency

Great Lakes Program Office

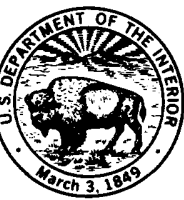

Madison, Wisconsin 


\section{UNITED STATES DEPARTMENT OF THE INTERIOR}

MANUEL LUJAN, JR., SECRETARY

\section{GEOLOGICAL SURVEY}

Dallas L. Peck, Director

For additional information

write to:

District Chief

U.S. Geological Survey

6417 Normandy Lane

Madison, Wisconsin
Copies of this report can be purchased from:

Open-File Services Section Western Distribution Branch U.S. Geological Survey Box 25425, Federal Center Denver, Colorado $\quad \mathbf{8 0 2 2 5}$ Telephone: (303) 234-5888 


\section{CONTENTS}

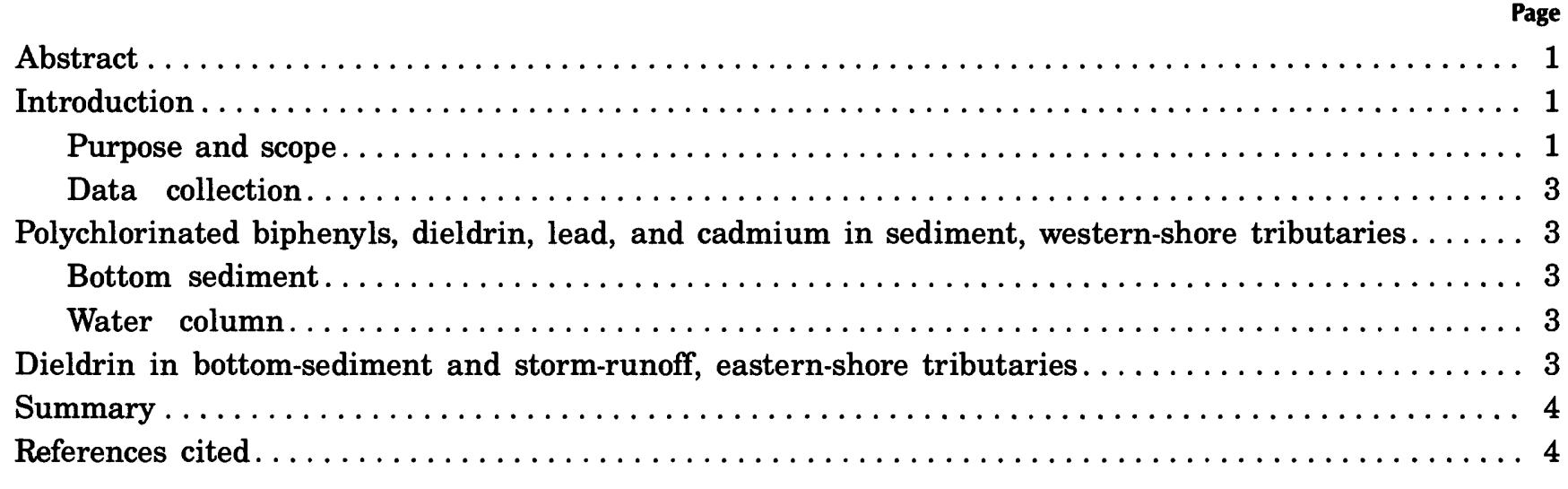

\section{ILLUSTRATIONS}

Figure 1. Map showing Green Bay tributary sampling-site locations.

\section{TABLES}

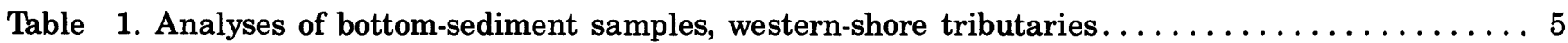

2. Analyses of water-column samples, western-shore tributaries. $\ldots \ldots \ldots \ldots \ldots \ldots \ldots \ldots$

3. Analyses of bottom-sediment and storm-runoff samples, eastern-shore tributaries. . . . . . 7 


\section{CONVERSION FACTORS AND ABBREVIATIONS}

For the convenience of readers who may prefer to use metric (International Systm) units rather than the inch-pound units used in this report, values may be converted by using the following factors:

Multiply inch-pound unit

foot $(\mathrm{ft})$

mile (mi)

cubic foot per second

$\left(\mathrm{ft}^{3 / \mathrm{s}}\right)$

ounce (oz)

pound (lb)

ton

gallon (gal)

cubic inch $\left(\mathrm{in}^{3}\right)$
By

0.3048

1.609

0.02832

28.35

0.4536

907.2

3.785

16.39
To obtain SI unit

meter (m)

kilometer (km)

cubic meter per second $\left(\mathrm{m}^{3} / \mathrm{s}\right)$

gram (g)

kilogram (kg)

kilogram (kg)

liter (L)

milliliter (mL)

Other units of measurement used in this report are:

milligrams per liter $(\mathrm{mg} / \mathrm{L})$

micrograms per liter $(\mu \mathrm{g} / \mathrm{L})$

nanograms per liter (ng/L) milligrams per kilogram (mg/kg)

micrograms per kilogram $(\mu \mathrm{g} / \mathrm{kg})$

micrograms per gram $(\mu \mathrm{g} / \mathrm{L})$ 


\title{
Data on Polychlorinated Biphenyls, Dieldrin, Lead, and Cadmium in Wisconsin and Upper Michigan Tributaries to Green Bay, July 1987 through April 1988
}

\author{
By
}

Leo B. House

\begin{abstract}
A reconnaissance study was conducted of 22 streams tributary to Green Bay to determine whether any of the streams contribute toxic substances to the bay. This effort was part of a comprehensive investigation of Green Bay funded by the U.S. Environmental Protection Agency, Great Lakes National Program Office.

The U.S. Geological Survey sampled the bottom sediments and water columns of 11 streams tributary to western Green Bay for polychlorinated biphenyls, lead, and cadmium. Four of these streams also were sampled for dieldrin, a pesticide previously used in the watershed. An additional 11 streams tributary to eastern Green Bay were sampled for dieldrin in the bottom sediment and storm runoff. Samples were collected from July 1987 through April 1988.

Neither dieldrin nor cadmium was detected in any of the sampled tributaries. Detectable concentrations of polychlorinated biphenyls and lead were found at only three sites. Polychorinated biphenyls $(0.10$ microgram per gram) and lead (10 milligrams per kilogram) were found in the bottom sediment of Duck Creek, a western-shore tributary near the city of Green Bay. Lead (10 milligrams per kilogram) also was found in the bottom sediment of the Suamico River near the mouth, about 5 miles north of Duck Creek. Lead (4 micrograms per liter) was detected in a spring-runoff sample from the Fishdam River, a tributary from upper Michigan.
\end{abstract}

\section{INTRODUCTION}

Green Bay is an arm of Lake Michigan adjacent to Wisconsin and the Upper Penninsula of Michigan (fig. 1). During 1987, the U.S. Environmental Protection Agency (EPA) began a comprehensive study of polychlorinated biphenyls (PCBs), dieldrin, lead, and cadmium in Green Bay. It was necessary to identify all significant sources of these target contaminants to quantify loadings to the bay. A previous investigation by Marti (1984) indicated that all the primary tributaries to Green Bay transported PCBs into the bay. Marti found that the Fox, the Menominee, the Oconto, the Peshtigo, and the Escanaba Rivers contained detectable concentrations of PCBs in water, as follows:

Fox River $\quad 97.3 \mathrm{ng} / \mathrm{L}$ (nanograms per liter) Menominee River $15.3 \mathrm{ng} / \mathrm{L}$

Oconto River $\quad 6.7 \mathrm{ng} / \mathrm{L}$

Peshtigo River $10.8 \mathrm{ng} / \mathrm{L}$

Escanaba River $17.1 \mathrm{ng} / \mathrm{L}$

During 1987 and 1988, the U.S. Geological Survey conducted a study of other important tributaries not investigated by Marti to determine whether they were significant sources of PCBs, dieldrin, lead, and cadmium. Laboratory analysis of samples was provided by the Wisconsin State Laboratory of Hygiene; funding was provided by the EPA.

\section{Purpose and Scope}

This report presents data collected by the U.S. Geological Survey during a water-sampling reconnaissance study of 22 tributaries to Green Bay (fig. 1). The EPA will use these data to determine whether any of these tributaries will be monitored during the comprehensive Green Bay Mass Balance Study of PCBs (U.S. Environmental Protection Agency, 1988).

Eleven of the tributaries studied are on the western shore of Green Bay and Michigan's Upper Penninsula; these were sampled for PCBs, lead, and 
(3) Eastern-shore tributary sampling site and number

A Western-shore tributary sampling site

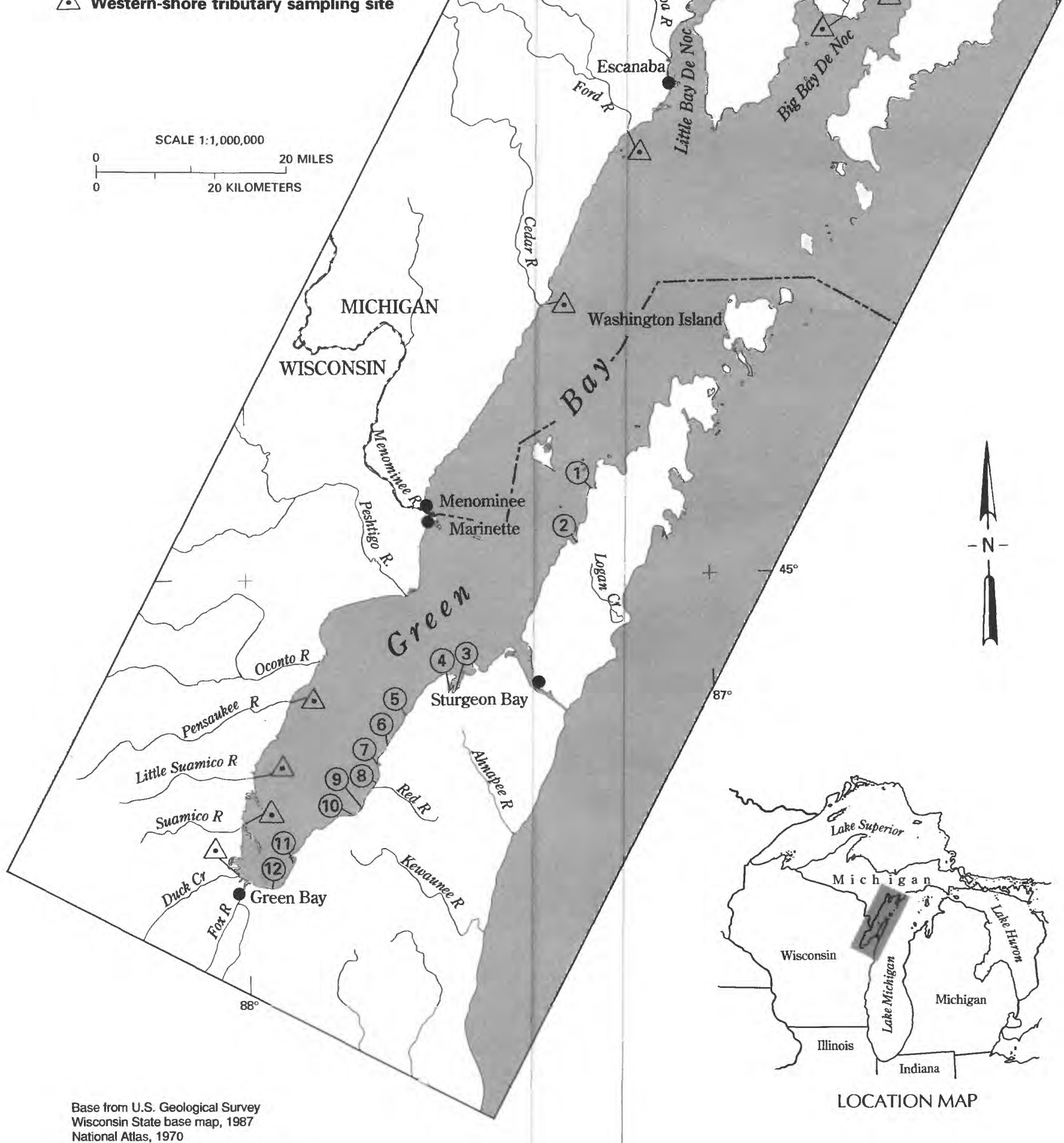

FIGURE 1. Map showing Green Bay tributary sampling-site locations. 
cadmium. Four of these streams also were sampled for dieldrin because of past pesticide use in their watersheds. Bottom-material samples were collected from each stream near its mouth in July 1987. Watercolumn samples were collected from each stream during low-flow conditions in August 1987 and again during higher flow conditions in November 1987. Spring-runoff water samples were collected during April 1988.

Eleven other sampled tributaries are on the eastern shore of Green Bay, primarily in Brown and Door Counties, Wisconsin. These 11 streams were sampled for dieldrin because of the past history of this pesticide's use in orchards in the area. Bottomsediment samples were collected from each stream near its mouth. Several storm-runoff water samples also were collected by local observers during the summer and fall of 1987.

\section{Data Collection}

Three samples of soft bottom sediment were collected from sites near the mouth of each river. Sample site " $A$ " is upstream from any reverse flow from Green Bay. Site $C$ is as close to the mouth as possible, and site $B$ is between the other sites. Bottom-sediment samples for PCB and dieldrin analysis were stored in solvent-rinsed glass jars with Teflon ${ }^{1}$ lids. Bottomsediment samples for lead and cadmium analysis were stored in 250-milliliter plastic bottles supplied by the Wisconsin State Laboratory of Hygiene. All samples were collected using Teflon-coated or metal grab samplers or scoops. Sampling equipment was rinsed with solvent prior to sample collection and again between sampling sites. All samples were chilled immediately after collection.

Water-column samples were collected using depth-integrating samplers at three verticals in a cross section. A 20-L (liter) water sample for analysis of PCBs was composited in a stainless steel pressure canister. All water samples were collected using a solvent-rinsed glass bottle in a weighted bottle holding device suspended on a rope. Where stream depth was too shallow to use the sampler, an integrated sample was collected along a transverse stream section using the stainless-steel canister directly. Care was taken not to collect bottom sediment in the water-column samples. Two additional 1-L water samples were collected for dieldrin analysis. Water samples collected for analysis for PCBs and dieldrin were immediately chilled; water samples collected for lead and cadmium analysis were preserved using nitric acid in ampules and then chilled. All water samples were delivered to the lab within 48 hours of collection.
Water-column analysis for PCBs was done using methods developed by Marti (1984). All other analyses were performed using standard methods and detection limits employed by the Wisconsin State Laboratory of Hygiene.

\section{POLYCHLORINATED BIPHENYLS, DIELDRIN, LEAD, AND CADMIUM IN WESTERN-SHORE TRIBUTARIES}

\section{Bottom Sediment}

Bottom-sediment samples from 11 tributary streams on the western shore of Green Bay (fig. 1) were analyzed for PCBs, dieldrin, lead, and cadmium. These samples were collected during July 20-22, 1987. Low concentrations of PCBs $[10 \mu \mathrm{g} / \mathrm{gm}$ (micrograms per gram)] and lead $[10 \mathrm{mg} / \mathrm{kg}$ (milligrams per kilogram)] were found in the bottom sediment of Duck Creek near the mouth. A low (10 $\mathrm{mg} / \mathrm{kg}$ ) concentration of lead was detected in the bottom sediment of the most downstream site of the Suamico River. Only samples from Duck Creek, Suamico, Little Suamico, and Pensaukee River were analyzed for dieldrin. Complete results of these analyses are presented in table 1.

\section{Water Column}

Water-column samples from the 11 westernshore tributaries were collected August 10-12 and November 2-4, 1987, and April 11-13, 1988. Only samples from Duck Creek, the Suamico, and the Pensaukee Rivers were analyzed for dieldrin. Lead [ $4 \mu \mathrm{g} / \mathrm{L}$ (micrograms per liter)] was detected only in the spring-runoff (April) sample from the Fishdam River. Cadmium was not detected in any sample. Complete results of these analyses are presented in table 2.

\section{DIELDRIN IN BOTTOM SEDIMENT AND STORM-RUNOFF, EASTERN-SHORE TRIBUTARIES}

Bottom-material samples from 11 tributary streams on the eastern shore of Green Bay (fig. 1) were collected on July 23, 1987 for dieldrin analysis. Stormrunoff samples were collected by local observers at three sites and shipped to the State Laboratory of Hygiene. Runoff samples were collected August 15 and 18 , November 17, and December 17, 1987. No detectable concentrations of dieldrin were found in any of these samples. The complete results of these analyses are presented in table 3 .

${ }^{1}$ Use of trade names in this report is for identification purposes only and does not constitute endorsement by the U.S. Geological Survey. 


\section{SUMMARY}

A low concentration of PCB $(0.10 \mu \mathrm{g} / \mathrm{g})$ and lead $(10 \mathrm{mg} / \mathrm{kg})$ was detected in the bottom sediment of Duck Creek near the mouth. This site is subject to reverse flow from Green Bay. A similar situation occurs at the most downstream site of the Suamico River, where a low concentration of lead $(10 \mathrm{mg} / \mathrm{kg})$ was detected in the bottom sediment. Lead $(4 \mu \mathrm{g} / \mathrm{L})$ was detected in the water-column sample from the Fishdam River, Michigan, site in the April 1988 spring-runoff sample. No other detectable concentration of PCB or lead was found in any water or sediment samples. Dieldrin and cadmium were not detected in any sample.

\section{REFERENCES CITED}

Marti, Edward, 1984, Polychlorinated biphenyls in 16 Lake Michigan tributaries: Madison, Wisconsin, University of Wisconsin Water Chemistry Department, M.S. Thesis, 247 p.

U.S. Environmental Protection Agency, 1988, Green Bay mass balance study plan: U.S. Environmental Protection Agency, Great Lakes National Program Office, Chicago, Illinois, 55 p. 
Table 1.-Analyses of bottom-sediment samples, western-shore tributaries

[ $\mu \mathrm{g} / \mathrm{g}$, micrograms per gram; mg/kg, milligrams per kilogram; -, no sample; <, less than]

\begin{tabular}{|c|c|c|c|c|c|}
\hline $\begin{array}{l}\text { River and } \\
\text { site number }\end{array}$ & Date & $\begin{array}{l}\text { PCB } \\
(\mu \mathbf{g} / \mathbf{g})\end{array}$ & $\begin{array}{c}\text { Dieldrin } \\
(\mu \mathrm{g} / \mathrm{g})\end{array}$ & $\underset{(\mathbf{m g} / \mathbf{k g})}{\text { Lead }}$ & $\underset{(\mathbf{m g} / \mathbf{k g})}{\text { Cadmium }}$ \\
\hline Fishdam River, & $7 / 21 / 87$ & & & & \\
\hline Site A & & $<0.05$ & - & $<5$ & $<1$ \\
\hline Site B & & $<.05$ & - & $<5$ & $<1$ \\
\hline Site C & & $<.05$ & - & $<5$ & $<1$ \\
\hline Sturgeon River, & $7 / 21 / 87$ & & & & \\
\hline Site A & & $<.05$ & - & $<5$ & $<1$ \\
\hline Site B & & $<.05$ & - & $<5$ & $<1$ \\
\hline Site C & & $<.05$ & - & $<5$ & $<1$ \\
\hline Whitefish River, & $7 / 21 / 87$ & & & & \\
\hline Site A & & $<.05$ & - & $<5$ & $<1$ \\
\hline Site B & & $<.05$ & - & $<5$ & $<1$ \\
\hline Site C & & $<.05$ & - & $<5$ & $<1$ \\
\hline Rapid River, & $7 / 21 / 87$ & & & & \\
\hline Site A & & $<.05$ & - & $<5$ & $<1$ \\
\hline Site B & & $<.05$ & - & $<5$ & $<1$ \\
\hline Site C & & $<.05$ & - & $<5$ & $<1$ \\
\hline Days River, & $7 / 20 / 87$ & & & & \\
\hline Site A & & $<.05$ & - & $<5$ & $<1$ \\
\hline Site B & & $<.05$ & - & $<5$ & $<1$ \\
\hline Site C & & $<.05$ & - & $<5$ & $<1$ \\
\hline Ford River, & $7 / 21 / 87$ & & & & \\
\hline Site A & & $<.05$ & - & $<5$ & $<1$ \\
\hline Site B & & $<.05$ & - & $<5$ & $<1$ \\
\hline Site C & & $<.05$ & - & $<5$ & $<1$ \\
\hline Cedar River, & $7 / 21 / 87$ & & & & \\
\hline Site A & & $<.05$ & - & $<5$ & $<1$ \\
\hline Site B & & $<.05$ & - & $<5$ & $<1$ \\
\hline Site C & & $<.05$ & - & $<5$ & $<1$ \\
\hline Pensaukee River, & $7 / 22 / 87$ & & & & \\
\hline Site A & & $<.05$ & $<0.01$ & $<5$ & $<1$ \\
\hline Site B & & $<.05$ & $<.01$ & $<5$ & $<1$ \\
\hline Site C & & $<.05$ & $<.01$ & $<5$ & $<1$ \\
\hline Suamico River, & $7 / 22 / 87$ & & & & \\
\hline Site A & & $<.05$ & $<.01$ & $<5$ & $<1$ \\
\hline Site B & & $<.05$ & $<.01$ & $<5$ & $<1$ \\
\hline $\begin{array}{l}\text { Site C } \\
\text { (near mouth) }\end{array}$ & & $<.05$ & $<.01$ & 10 & $<1$ \\
\hline Little Suamico, & $7 / 22 / 87$ & & & & \\
\hline Site A & & $<.05$ & $<.01$ & $<5$ & $<1$ \\
\hline Site B & & $<.05$ & $<.01$ & $<5$ & $<1$ \\
\hline Site C & & $<.05$ & $<.01$ & $<5$ & $<1$ \\
\hline Duck Creek, & $7 / 22 / 87$ & & & & \\
\hline Site A & & $<.05$ & $<.01$ & $<5$ & $<1$ \\
\hline Site B & & $<.05$ & $<.01$ & $<5$ & $<1$ \\
\hline $\begin{array}{l}\text { Site C } \\
\text { (near mouth) }\end{array}$ & & .10 & $<.01$ & 10 & $<1$ \\
\hline
\end{tabular}


Table 2.-Analyses of water-column samples, western-shore tributaries

[ft $\mathrm{t}^{\mathrm{3}} / \mathrm{s}$, cubic feet per second; $\mathrm{mg} / \mathrm{L}$, milligrams per liter; $\mathrm{ng} / \mathrm{L}$, nanograms per liter; $\mu \mathrm{g} / \mathrm{L}$, micrograms per liter; - , no sample; $<$, less than]

\begin{tabular}{|c|c|c|c|c|c|c|}
\hline $\begin{array}{l}\text { River and } \\
\text { date }\end{array}$ & $\begin{array}{c}\text { Discharge } \\
\left(\mathbf{f t}^{3} / \mathbf{s}\right)\end{array}$ & $\begin{array}{l}\text { Sediment } \\
(\mathbf{m g} / \mathbf{L})\end{array}$ & $\begin{array}{c}\text { PCB } \\
\text { (ng/L) }\end{array}$ & $\begin{array}{c}\text { Dieldrin } \\
(\mu \mathbf{g} / \mathbf{L})\end{array}$ & $\begin{array}{l}\text { Lead } \\
(\mu \mathrm{g} / \mathrm{L})\end{array}$ & $\begin{array}{c}\text { Cadmium } \\
(\mu \mathbf{g} / \mathbf{L})\end{array}$ \\
\hline \multicolumn{7}{|c|}{ Fishdam River, } \\
\hline $8 / 10 / 87$ & 22.2 & 6.5 & $<15$ & - & - & - \\
\hline $11 / 3 / 87$ & 46.1 & 8.1 & $<40$ & - & - & - \\
\hline $4 / 12 / 88$ & 187 & 41.7 & $<15$ & - & 4 & $<0.2$ \\
\hline \multicolumn{7}{|c|}{ Sturgeon River, } \\
\hline $8 / 10 / 87$ & 99.3 & 5.8 & $<15$ & - & - & - \\
\hline $11 / 3 / 87$ & 146 & 4.1 & $<40$ & - & - & - \\
\hline $4 / 12 / 88$ & 809 & 28.3 & $<15$ & - & $<3$ & $<.2$ \\
\hline \multicolumn{7}{|c|}{ Whitefish River, } \\
\hline $8 / 11 / 87$ & 127 & 1.4 & $<15$ & - & - & - \\
\hline $11 / 3 / 87$ & 231 & 2.9 & $<40$ & - & - & - \\
\hline $4 / 12 / 88$ & 1,380 & 8.0 & $<15$ & - & $<3$ & $<.2$ \\
\hline \multicolumn{7}{|l|}{ Rapid River, } \\
\hline $8 / 11 / 87$ & 66.2 & 1.5 & $<15$ & - & - & - \\
\hline $11 / 3 / 87$ & 90.8 & 2.2 & $<40$ & - & - & - \\
\hline $4 / 13 / 88$ & 418 & 16.2 & $<15$ & - & $<3$ & $<.2$ \\
\hline \multicolumn{7}{|l|}{ Days River, } \\
\hline $8 / 11 / 87$ & 31.2 & 1.6 & $<15$ & - & - & - \\
\hline $11 / 2 / 87$ & 28.7 & 5.0 & $<40$ & - & - & - \\
\hline $4 / 11 / 88$ & 216 & 34.2 & $<15$ & - & $<3$ & $<.2$ \\
\hline \multicolumn{7}{|l|}{ Ford River, } \\
\hline $8 / 12 / 87$ & 166 & 1.9 & $<15$ & - & - & - \\
\hline $11 / 3 / 87$ & 217 & 2.5 & $<40$ & - & - & - \\
\hline $4 / 13 / 88$ & 1,350 & 8.0 & $<15$ & - & $<3$ & $<.2$ \\
\hline \multicolumn{7}{|l|}{ Cedar River, } \\
\hline 8/12/87 & 73.5 & 1.6 & $<15$ & - & - & - \\
\hline $11 / 4 / 87$ & 156 & 4.9 & $<40$ & - & - & - \\
\hline 4/11/88 & 1,670 & 12.8 & $<15$ & - & $<3$ & $<.2$ \\
\hline \multicolumn{7}{|c|}{ Pensaukee River, } \\
\hline $8 / 11 / 87$ & 29.0 & 9.4 & $<15$ & $<0.05$ & - & - \\
\hline $11 / 2 / 87$ & 11.0 & 19.6 & $<40$ & $<.05$ & - & - \\
\hline $4 / 11 / 88$ & 107 & 8.3 & $<15$ & $<.05$ & $<3$ & $<.2$ \\
\hline \multicolumn{7}{|c|}{ Suamico River, } \\
\hline $8 / 11 / 87$ & 4.9 & 9.3 & $<15$ & $<.05$ & - & - \\
\hline $11 / 2 / 87$ & 7.7 & 39.6 & $<40$ & $<.05$ & - & - \\
\hline 4/11/88 & 27.5 & 16.5 & $<15$ & $<.05$ & $<3$ & $<.2$ \\
\hline \multicolumn{7}{|c|}{ Little Suamico, } \\
\hline 8/11/87 & 3.3 & 1.7 & $<15$ & - & - & - \\
\hline $11 / 2 / 87$ & 5.2 & 13.1 & $<40$ & - & - & - \\
\hline 4/11/88 & 28.6 & 14.1 & $<15$ & - & $<3$ & $<.3$ \\
\hline \multicolumn{7}{|l|}{ Duck Creek, } \\
\hline $8 / 11 / 87$ & 1.2 & 8.6 & $<15$ & $<.05$ & - & - \\
\hline 11/3/87 & 3.4 & 23.8 & $<200$ & $<.05$ & - & - \\
\hline No sa & ected during $\mathrm{s}$ & g runoff. & & & & \\
\hline
\end{tabular}


Table 3.-Analyses of bottom-sediment samples and storm-runoff samples, eastern-shore tributaries $[\mu \mathrm{g} / \mathrm{g}$, micrograms per gram; $\mu \mathrm{g} / \mathrm{L}$, micrograms per liter; - , no sample; $<$, less than]

\begin{tabular}{|c|c|c|c|}
\hline $\begin{array}{l}\text { Sampling site name } \\
\text { and number }\end{array}$ & $\begin{array}{l}\text { Sample } \\
\text { date }\end{array}$ & $\begin{array}{c}\text { Bottom } \\
\text { sediment } \\
\text { dieldrin } \\
(\mu \mathrm{g} / \mathrm{g})\end{array}$ & $\begin{array}{c}\text { Water } \\
\text { column } \\
\text { dieldrin } \\
(\mu \mathrm{g} / \mathrm{L})\end{array}$ \\
\hline $\begin{array}{l}\text { Fish Creek near State Highway } 42 \\
\text { bridge, site number } 1\end{array}$ & $\begin{array}{c}7 / 23 / 87 \\
11 / 17 / 87 \\
12 / 17 / 87\end{array}$ & $\begin{array}{c}<0.01 \\
- \\
-\end{array}$ & $\begin{array}{l}-\overline{0.05} \\
<.05\end{array}$ \\
\hline \multicolumn{4}{|l|}{$\begin{array}{l}\text { Unnamed tributary. No samples } \\
\text { collected. Site number } 2\end{array}$} \\
\hline $\begin{array}{l}\text { Unnamed tributary to Little } \\
\text { Sturgeon Bay near County C } \\
\text { bridge, site number } 3\end{array}$ & $7 / 23 / 87$ & $<.01$ & - \\
\hline $\begin{array}{l}\text { Keyes Creek at County } \mathrm{C} \text { bridge, } \\
\text { site number } 4\end{array}$ & $\begin{array}{l}7 / 23 / 87 \\
8 / 18 / 87\end{array}$ & $<.01$ & $<-.05$ \\
\hline $\begin{array}{l}\text { Sugar Creek at Sugar Creek Park, } \\
\text { site number } 5\end{array}$ & $7 / 23 / 87$ & $<.01$ & - \\
\hline $\begin{array}{l}\text { Unnamed tributary to Green Bay } \\
\text { near Highway N, site number } 6\end{array}$ & $7 / 23 / 87$ & $<.01$ & - \\
\hline $\begin{array}{l}\text { Renard Creek at Shoemaker Road } \\
\text { bridge, site number } 7\end{array}$ & $7 / 23 / 87$ & $<.01$ & - \\
\hline $\begin{array}{l}\text { Red River at State Highway } 57 \text {, } \\
\text { site number } 8\end{array}$ & $\begin{array}{l}7 / 23 / 87 \\
8 / 15 / 87\end{array}$ & $\begin{array}{c}<.01 \\
-\end{array}$ & $<.05$ \\
\hline $\begin{array}{l}\text { Kewaunee River at State Highway } \\
57 \text { near Dykesville, } \\
\text { site number } 9\end{array}$ & $7 / 23 / 87$ & $<.01$ & - \\
\hline $\begin{array}{l}\text { Gilson Creek near State Highway } \\
\text { 57, site number } 10\end{array}$ & $7 / 23 / 87$ & $<.01$ & - \\
\hline $\begin{array}{l}\text { Unnamed tributary to Green Bay } \\
\text { at County } A \text {, site number } 11\end{array}$ & $7 / 23 / 87$ & $<.01$ & - \\
\hline $\begin{array}{l}\text { Unnamed Creek at County A } \\
\text { near U. W. Green Bay campus, } \\
\text { site number } 12\end{array}$ & $7 / 23 / 87$ & $<.01$ & - \\
\hline
\end{tabular}

